\title{
Mercury and Methylmercury Contamination of Fish from the Skalka Reservoir: A Case Study
}

\author{
P. MARŠÁLEK ${ }^{1,2}$, Z. SVOBODOVÁ ${ }^{1,3}$, T. RANDÁK ${ }^{3}$, J.ŠVEHLA $^{4}$ \\ ${ }^{1}$ University of Veterinary and Pharmaceutical Science, Brno \\ ${ }^{2}$ State Veterinary Institute, Brno \\ ${ }^{3}$ University of South Bohemia in České Budějovice, Research Institute of Fish Culture \\ and Hydrobiology, Vodňany \\ ${ }^{4}$ University of South Bohemia, Faculty of Agriculture, České Budějovice \\ Received February 27, 2005 \\ Accepted June 6, 2005
}

\begin{abstract}
Maršálek P., Z. Svobodová, T. Randák, J.Švehla: Mercury and Methylmercury Contamination of Fish from the Skalka Reservoir: A Case Study. Acta Vet. Brno 2005, 74: 427-434.

The aim of this case study was to investigate the total mercury and methylmercury contamination of fish from the Skalka reservoir, Czech Republic. The reservoir had been polluted with mercurycontaining sewage water for several decades. In total, 30 fish was sampled in August 2003. The fish caught included 5 roach (Rutilus rutilus), 8 bream (Abramis brama), 2 silver bream (Blicca bjoerkna), 7 big head carp (Aristichthys nobilis), 4 asp (Aspius aspius), 3 eel (Anguilla anguilla) and 1 wels catfish (Silurus glanis). Muscle tissue, the liver and the gonads were used for mercury determination. Total mercury in muscle tissue of the asp (as the representative of predatory species) and the bream (as the representative of non-predatory species) averaged $3.11 \pm 0.20 \mathrm{mg} \cdot \mathrm{kg}^{-1}$ and $0.96 \pm 0.22 \mathrm{mg} \cdot \mathrm{kg}^{-1}$, respectively. All total mercury in muscle tissue of the asp and the bream was in methylmercury form. The content of total mercury and methylmercury was significantly $(p<0.05)$ higher in muscle tissue and the liver than in the gonads. The methylmercury-to-total mercury ratio in muscle tissue, the liver and the gonads averaged 1.012, 0.545 and 0.907 , respectively. The results showed that mercury contamination of the Skalka reservoir continues to be very high, that consumption of predatory fish in particular poses a major health risk and that methylmercury was the predominant contaminant in fish tissues.
\end{abstract}

Total mercury, methylmercury, $\mathrm{MeHg} / \mathrm{THg}$ ratio, bream, big head carp, roach, asp, muscle, liver, gonads, freshwater fish

For several decades, the rivers of Reslava and Ohře and the Skalka reservoir near Cheb, west Bohemia, were polluted with mercury-contaminating sewage water from a factory that manufactured mercury-based technical chemicals and preparations in Marktredwitz (Germany). Its sewage water was discharged to the stream Kösseine and went to the rivers Reslava and Ohře. The monitoring of mercury contamination levels in the Ohře, its tributaries and the Skalka reservoir was started in 1974 due to initiative of the State WaterManagement Inspectorate (Hejtmánek et al. 1975; Svobodová et al. 1976). Depending on fish species, the range of average muscle tissue total mercury ( $\mathrm{THg}$ ) content was $0.14-0.49 \mathrm{mg} \cdot \mathrm{kg}^{-1}$ wet weight (w.w.), $0.20-0.91 \mathrm{mg} \cdot \mathrm{kg}^{-1} \mathrm{w} . \mathrm{w}$. and $0.10-0.52 \mathrm{mg} \cdot \mathrm{kg}^{-1} \mathrm{w}$. w. in the Skalka reservoir, in the Reslava and in the Ohře, respectively. Although mercury contamination of sewage water fell below the statutory limit $0.05 \mathrm{mg} \cdot \mathrm{l}^{-1}$ in the second half of the 1970s (V o ndrák et al. 1984), the 1980s saw a marked increase in fish mercury contamination. Levels of mercury contamination in fish caught in 1990, 1995 and 1996 in the rivers Reslava and Ohře and in the Skalka reservoir mostly greatly exceeded the statutory limit $0.5 \mathrm{mg} \cdot \mathrm{kg}^{-1}$ w.w. and some levels were very high (e.g. $4.43 \mathrm{mg} \cdot \mathrm{kg}^{-1} \mathrm{w} . \mathrm{w}$. in muscle tissue of eel and $3.40 \mathrm{mg} \cdot \mathrm{kg}^{-1} \mathrm{w} . \mathrm{w}$. in perch). Mercury contamination ascertained in the perch liver reached $39.7 \mathrm{mg} \cdot \mathrm{kg}^{-1}$ w.w. (Černá and Hrabětová 1996; Svobodová et al.

Address for correspondence:

Mgr. Petr Maršálek

University of Veterinary and Pharmaceutical Sciences

Department of Veterinary Public Health and Toxicology

Palackého 1-3, 61242 Brno, Czech Republic
Phone: $+420737611508,+420541562788$

Fax: + 420541562780

E-mail: petrmarsalek@seznam.cz

http://www.vfu.cz/acta-vet/actavet.htm 
1997). The most likely cause of the increase was the burst sewage water pipeline in the factory in 1984. The Marktredwitz factory was then closed down. The entire basin was contaminated again in 1994 during Kösseine stream rehabilitation works when the contaminated sediments were exposed and washed away. The situation was aggravated by the changes in water level height, particularly in 1976 and 1982, when the reservoir was completely drained and filled with water again, followed by a twofold increase in total mercury levels in fish.

Mercury in water ecosystems occurs in several forms including elementary $\left(\mathrm{Hg}^{0}\right)$, inorganic $\left(\mathrm{Hg}+\right.$ or, rather, $\mathrm{Hg}^{0}$ added to $\mathrm{Hg}^{2+}$ and $\mathrm{Hg}^{2+}$ ) and organic forms of mercury, primarily monomethylmercury $\left(\mathrm{CH}_{3} \mathrm{Hg}^{+}\right)$and dimethylmercury $\left[\left(\mathrm{CH}_{3}\right)_{2} \mathrm{Hg}\right]$. The type of mercury predominantly occurring (in up to $100 \%$ ) in tissues of a majority of fish species is monomethylmercury (MeHg) (Mas on et al. 1995; Kannan et al. 1998; Porcella 1994), whose neurotoxicity (Igata 1986) makes it the most toxic form of mercury (WHO 1990). It is produced by microbial methylation in sediments (Jernelöv 1973; Compeau and Bartha 1985), infiltrates the food chain and is consequently accumulated in fish. $\mathrm{MeHg}$ bioaccumulation in fish tissues increases with fish age and thus also their size (Norstrom et al. 1976; J ewett et al. 2003). Fish are the main source of methylmercury contamination of people (WHO 1990). This makes them the main target in aqueous system contamination monitoring for both environmental and food safety purposes.

The aims of the present study were:

- to assess the contemporary mercury contamination levels in the Skalka reservoir and to compare them with historical figures

- to compare methylmercury-to-total mercury ratios in different tissues of the fish species studied

- to assess the health risks posed by fish consumption from the Skalka reservoir.

\section{Materials and Methods}

Location

The Skalka reservoir (Fig. 1) is located in a valley in western Bohemia on the river Ohře near the border with Germany. The reservoir was built in 1964 , and its surface area is $3.78 \mathrm{~km}^{2}$. The reservoir is managed by the Povodí Ohře company. The main purpose of the reservoir is to provide for at least minimum flow rates in the river Ohře. The reservoir should also provide a degree of protection of areas downstream of its dam against floods, generate hydroelectricity, and serve as a place for angling, recreation and water sports.

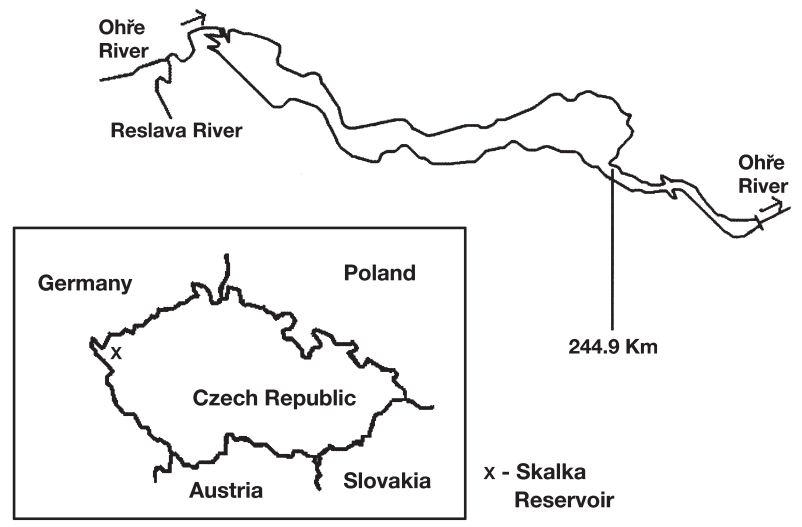

Fig. 1. Skalka reservoir near Cheb and the site where fish were caught

Material

The fish from the Skalka reservoir was caught in August 2003. The fish were caught at 244.9 river km using toils, scoop nets and hook and bait. A total of 30 fish was caught (Table 1). The fish caught included 5 roach (Rutilus rutilus), 8 bream (Abramis brama), 2 silver bream (Blicca bjoerkna), 7 big head carp (Aristichthys nobilis), 4 asp 
(Aspius aspius), 3 eel (Anguilla anguilla) and 1 wels catfish (Silurus glanis). The fish were weighed and their scales collected for age determination. Samples of muscle tissues, the liver and the gonads were then collected, frozen in plastic bags at $-20^{\circ} \mathrm{C}$ and analyzed during the next 1 or 2 months.

Table 1. Characteristics of the fish

\begin{tabular}{|c|c|c|c|}
\hline Species & $\mathrm{n}$ & $\begin{array}{c}\text { Weight }(\mathrm{g}) \\
\text { mean } \pm \text { SD } \\
\text { range }\end{array}$ & $\begin{array}{c}\text { Age (years) } \\
\text { mean } \pm \text { SD } \\
\text { range }\end{array}$ \\
\hline Big head carp & 7 & $\begin{array}{c}10042 \pm 5290 \\
(3300-18000)\end{array}$ & $\begin{array}{c}11.1 \pm 5.3 \\
(4-19)\end{array}$ \\
\hline Bream & 8 & $\begin{array}{c}764 \pm 331 \\
(85-1165)\end{array}$ & $\begin{array}{c}5.4 \pm 1.4 \\
(3-7)\end{array}$ \\
\hline Roach & 5 & $\begin{array}{c}221 \pm 130 \\
(75-370)\end{array}$ & $\begin{array}{c}3.8 \pm 1.3 \\
(2-5)\end{array}$ \\
\hline Silver bream & 2 & 255,300 & 5 \\
\hline Asp & 4 & $2001 \pm 219$ & $5.5 \pm 0.5$ \\
& & $(1680-2175)$ & $(5-6)$ \\
\hline Eel & 3 & $308 \pm 105$ & N/A \\
& & $(190-390)$ & 4 \\
\hline Wels & 1 & 2500 & \\
\hline
\end{tabular}

Analytical methods

Total mercury content in fish tissues was determined by the direct method of cold vapours using an AMA 254 (Altec Ltd.) analyzer. $\mathrm{MeHg}$ was determined in the form of a $\mathrm{MeHgCl}$ by gas chromatography. Samples were prepared by acidic digestion and extraction to toluene (AOAC 1992). For the determination, Hewlet Packard 5890 Series II gas chromatograph was used. A capillary column DB 608 (30 m) (Caric chia et al. 1997) and an electron capture detector (ECD) were used. Evaluation was made using HP 3365 ChemStation Series II software (Hewlet Packard). All solvents used met residual trace analysis quality parameters. Total mercury (THg) and methylmercury $\left(\mathrm{MeHg}\right.$ ) contents are given in $\mathrm{mg} \cdot \mathrm{kg}^{-1}$ wet weight (w.w.)

Result quality assurance

BCR 463 and BCR 464 (IRMM Belgie) reference materials were used to validate the methods and to determine the uncertainties. Detection limits for total mercury and methylmercury determination methods were $0.001 \mathrm{mg} \cdot \mathrm{kg}^{-1}$ and $0.01 \mathrm{mg} \cdot \mathrm{kg}^{-1}$, respectively. Extended uncertainty for total mercury and $\mathrm{MeHg}$ determination methods were $10 \%$ and $12 \%$, respectively. The methods were successfully tested in the inter-laboratory comparison test IMEP-20 Trace Elements in Tuna Fish. The analysis of variance (ANOVA) was used for testing of species and tissues differences and the Spearman correlation was used for testing of relation of $\mathrm{THg}$ and $\mathrm{MeHg}$ contents to the weight and age of the fish. Statistical calculations were carried out using QC Expert software (Trilobyte Ltd.).

\section{Results and Discussion}

The results of fish tissues analysis for total mercury ( $\mathrm{THg}$ ) and methylmercury ( $\mathrm{MeHg}$ ) contents are given in Table 2. Fish of both sexes were evaluated together in the rest of the study.

\section{Total mercury ( $\mathrm{THg})$}

The significantly highest THg content in muscle tissue $(p<0.05)$ was found in asp followed by eel and big head carp, bream and roach. There were no significant differences in muscle tissue THg contents between big head carp, bream and roach. THg content in the liver was significantly higher $(p<0.05)$ in asp and eel than in bream and roach. Big head carp liver THg levels showed no significant differences compared with other species. This was due to the high variability of big head carp liver THg levels (Table 2) and particularly by their three high scattered values $\left(11.6,20.3\right.$ and $\left.24.9 \mathrm{mg} \cdot \mathrm{kg}^{-1}\right)$. THg content in asp gonads was significantly higher $(p<0.05)$ than in the gonads of big head carp, bream and roach. Differences in contamination were evaluated only in the species where 3 or more samples 
Table 2. Total mercury ( $\mathrm{THg}$ ) and methylmercury $(\mathrm{MeHg})$ concentrations in samples of muscle tissue, the liver and the gonads of different fish species (in $\mathrm{mg} / \mathrm{kg} \mathrm{w}$.w.) and methylmercury-to-total mercury ratios

\begin{tabular}{|c|c|c|c|c|c|}
\hline Species & Tissue & $\mathrm{n}$ & $\begin{array}{c}\mathrm{MeHg}\left(\mathrm{mg} \cdot \mathrm{kg}^{-1}\right) \\
\text { mean } \pm \mathrm{SD} \\
\text { range }\end{array}$ & $\begin{array}{c}\mathrm{THg}\left(\mathrm{mg}^{\mathrm{kg}} \mathrm{kg}^{-1}\right) \\
\text { mean } \pm \mathrm{SD} \\
\text { range }\end{array}$ & $\begin{array}{c}\mathrm{MeHg} / \mathrm{THg} \\
\text { mean } \pm \mathrm{SD} \\
\text { range }\end{array}$ \\
\hline $\begin{array}{l}\text { Big head } \\
\text { carp }\end{array}$ & $\begin{array}{l}\text { muscle } \\
\text { liver } \\
\text { gonads }\end{array}$ & $\begin{array}{l}7 \\
7 \\
7\end{array}$ & $\begin{array}{c}0.90 \pm 0.28 \\
(0.56-1.26) \\
0.70 \pm 0.30 \\
(0.29-1.07) \\
0.19 \pm 0.07 \\
(0.11-0.31)\end{array}$ & $\begin{array}{c}0.83 \pm 0.21 \\
(0.53-1.04) \\
8.81 \pm 10.2 \\
(0.42-24.89) \\
0.25 \pm 0.13 \\
(0.1-0.42)\end{array}$ & $\begin{array}{c}1.01 \pm 0.18 \\
(0.64-1.15) \\
0.33 \pm 0.29 \\
(0.02-0.64) \\
0.80 \pm 0.25 \\
(0.38-1.02)\end{array}$ \\
\hline Bream & $\begin{array}{l}\text { muscle } \\
\text { liver } \\
\text { gonads }\end{array}$ & 8 & $\begin{array}{c}1.04 \pm 0.24 \\
(0.59-1.33) \\
0.75 \pm 0.26 \\
(0.29-1.03) \\
0.55 \pm 0.26 \\
(0.24-1.05)\end{array}$ & $\begin{array}{c}0.96 \pm 0.22 \\
(0.55-1.23) \\
1.50 \pm 0.70 \\
(0.63-2.98) \\
0.52 \pm 0.23 \\
(0.23-0.96)\end{array}$ & $\begin{array}{c}1.01 \pm 0.06 \\
(0.94-1.15) \\
0.48 \pm 0.10 \\
(0.30-0.61) \\
0.98 \pm 0.06 \\
(0.83-1.03) \\
\end{array}$ \\
\hline Roach & $\begin{array}{l}\text { muscle } \\
\text { liver } \\
\text { gonads }\end{array}$ & $\begin{array}{l}5 \\
5 \\
5\end{array}$ & $\begin{array}{c}0.87 \pm 0.29 \\
(0.65-1.37) \\
0.73 \pm 0.43 \\
(0.44-1.37) \\
0.30 \pm 0.19 \\
(0.18-0.63) \\
\end{array}$ & $\begin{array}{c}0.81 \pm 0.28 \\
(0.58-1.27) \\
0.88 \pm 0.52 \\
(0.39-1.69) \\
0.28 \pm 0.18 \\
(0.16-0.59) \\
\end{array}$ & $\begin{array}{c}1.01 \pm 0.03 \\
(0.97-1.04) \\
0.88 \pm 0.15 \\
(0.75-1.04) \\
1.01 \pm 0.03 \\
(0.97-1.05) \\
\end{array}$ \\
\hline $\begin{array}{l}\text { Silver } \\
\text { bream }\end{array}$ & $\begin{array}{c}\text { muscle } \\
\text { liver } \\
\text { gonads }\end{array}$ & $\begin{array}{l}2 \\
2 \\
2\end{array}$ & $\begin{array}{c}0.91-0.99 \\
0.21-0.99 \\
0.35\end{array}$ & $\begin{array}{l}0.81-0.91 \\
0.31-1.62 \\
0.31-0.80\end{array}$ & $\begin{array}{c}1.01-1.05 \\
0.57-0.63 \\
1.05\end{array}$ \\
\hline Asp & $\begin{array}{l}\text { muscle } \\
\text { liver } \\
\text { gonads }\end{array}$ & $\begin{array}{l}4 \\
4 \\
4\end{array}$ & $\begin{array}{c}3.41 \pm 0.45 \\
(3.00-4.05) \\
4.36 \pm 1.71 \\
(2.84-6.81) \\
1.80 \pm 0.44 \\
(1.25-2.31)\end{array}$ & $\begin{array}{c}3.11 \pm 0.20 \\
(2.93-3.40) \\
6.24 \pm 1.67 \\
(4.19-8.20) \\
1.71 \pm 0.38 \\
(1.17-2.08)\end{array}$ & $\begin{array}{c}1.02 \pm 0.09 \\
(0.91-1.11) \\
0.67 \pm 0.20 \\
(0.47-0.95) \\
0.98 \pm 0.05 \\
(0.91-1.03)\end{array}$ \\
\hline Eel & $\begin{array}{l}\text { muscle } \\
\text { liver }\end{array}$ & $\begin{array}{l}3 \\
3\end{array}$ & $\begin{array}{c}1.85 \pm 0.23 \\
(1.66-2.11) \\
2.89 \pm 2.01 \\
(1.72 \pm 5.21) \\
\end{array}$ & $\begin{array}{c}1.80 \pm 0.40 \\
(1.52-2.26) \\
4.46 \pm 3.27 \\
(2.50-8.23) \\
\end{array}$ & $\begin{array}{c}0.96 \pm 0.08 \\
(0.87-1.02) \\
0.61 \pm 0.03 \\
(0.59-0.65)\end{array}$ \\
\hline Wels & $\begin{array}{c}\text { muscle } \\
\text { liver }\end{array}$ & $\begin{array}{l}1 \\
1 \\
\end{array}$ & $\begin{array}{l}1.11 \\
1.01 \\
\end{array}$ & $\begin{array}{l}0.96 \\
1.03 \\
\end{array}$ & $\begin{array}{l}1.07 \\
0.91 \\
\end{array}$ \\
\hline
\end{tabular}

were available. Higher THg contents in asp and eel reflect their position in the food chain and show that higher total mercury levels will be found in predatory fish than in nonpredatory fish species, which has also been corroborated by findings of other authors (Jewett et al. 2003; Brabo et al. 2000; Peňáz et al. 1979). The higher level of THg in asp compared with eel can probably be ascribed to their different diets and also their different ability to migrate (B aruš et al. 1985ab)

$\mathrm{THg}$ distribution was evaluated for each species separately. Only species with at least three fish available were evaluated. Asp, big head carp and bream had significantly the highest $(p<0.05) \mathrm{THg}$ contents in the liver followed by muscle tissue and the gonads. Roach had a significantly higher THg content $(p<0.05)$ in muscle tissue and the liver than in the gonads. Eel showed no significant difference in THg contents between muscle tissue and the 
liver. Results in all species studied showed that the lowest THg levels were in the gonads. While THg levels in the liver and muscle tissue were different in the individual species, it was true in most of them that liver THg levels were higher. The distribution in tissues of different fish species from the Skalka reservoir corresponded to that found in fish from the Želivka reservoir, i.e. significantly higher levels in the liver than in muscle tissue were found in asp and bream. Roach had significantly higher levels in muscle tissue than in the liver. The lowest $\mathrm{THg}$ level in all species from the Želivka reservoir was found in the gonads (Svobodová et al. 1988)

\section{Methylmercury and methylmercury-to-total mercury ratio}

After the conversion of $\mathrm{MeHg}$ to elementary mercury content, it was clear that almost $100 \%$ of mercury in muscle tissue and the gonads was $\mathrm{MeHg}$ (Table 2). The MeHg-to$\mathrm{THg}$ ratio was significantly higher $(p<0.01)$ in muscle tissue $(1.01 \pm 0.19$; median $=$ $1.01)$ and the gonads $(0.94 \pm 0.15$; median $=1.00)$ than in the liver $(0.57 \pm 0.25$; median $=0.59$ ). This fact indicates a higher proportion of inorganic mercury in the liver. Jew et et al. (2003) also reported a higher proportion of $\mathrm{MeHg}$ in $\mathrm{THg}$ in muscle tissue than in the liver, which is probably due to $\mathrm{MeHg}$ demethylation taking place there. $\mathrm{MeHg}$ values exceeding $100 \%$ are due to error in determination of both $\mathrm{THg}$ and $\mathrm{MeHg}$. The correlation between $\mathrm{THg}$ and $\mathrm{MeHg}$ levels was assessed by the linear regression method. Values from each tissue were tested separately. In all three tissues, significant $(p<0.01)$ correlation between $\mathrm{THg}$ and $\mathrm{MeHg}$ contents was found. The correlation coefficients for muscles, livers and gonads were $r=0.983(n=30), r=0.932(n=27)$ and $r=0.993(n=27)$, respectively. Three THg values had to be discarded from big head carp liver correlation assessments as too widely scattered. A significant correlation between $\mathrm{MeHg}$ and $\mathrm{THg}$ contents confirms the key role of $\mathrm{MeHg}$ in $\mathrm{Hg}$ accumulation in fish tissues.

To evaluate the differences in MeHg contamination between different species, results in asp, big head carp, bream, roach and eel were used. A comparison between $\mathrm{MeHg}$ levels in muscle tissue of the individual fish species $(p<0.05)$ produced the following order: asp > eel > big head carp, roach and bream. Liver MeHg content was significantly higher $(p<0.05)$ in asp and eel than in big head carp, bream and roach. MeHg content in asp gonads was significantly higher $(p<0.05)$ than in the gonads of big head carp, bream and roach. The results indicate higher $\mathrm{MeHg}$ levels in predatory species compared with non-predatory ones, which corresponds to differences in $\mathrm{THg}$ levels between the species.

As far as the distribution of $\mathrm{MeHg}$ in fish tissues is concerned, big head carp and bream had significantly $(p<0.05)$ the highest $\mathrm{MeHg}$ contents in muscle tissue, lower in the liver and the lowest in the gonads. Asp and roach had significantly higher MeHg content $(p<$ 0.05 ) in muscle tissue and the liver than in the gonads. Eel showed no significant difference in $\mathrm{MeHg}$ contents between muscle tissue and the liver. Results of $\mathrm{MeHg}$ distribution showed that the lowest $\mathrm{MeHg}$ levels were in the gonads in all fish species studied. As with THg, a comparison between the liver and muscle tissue shows interspecies differences. Contrary to $\mathrm{THg}$, however, $\mathrm{MeHg}$ levels in muscle tissue were higher than, or equal to, $\mathrm{MeHg}$ levels in the liver. This fact is probably due to the demethylation of $\mathrm{MeHg}$ in the liver and it serves to confirm the results of the $\mathrm{MeHg} / \mathrm{THg}$ ratio assessment between the individual tissues.

The relation of THg and $\mathrm{MeHg}$ contents to the weight and age of the fish was tested by the Spearman correlation method. Significant correlations $(p<0.1)$ between mercury content and fish weight were found for $\mathrm{MeHg}$ in muscle tissue and the liver of big head carp $(\mathrm{r}=$ 0.75 a $r=0.96 ; n=7)$ and for THg in muscle tissue of big head carp $(r=0.65 ; n=7)$. Significant correlations $(p<0.1)$ between mercury content and fish age were found for 
$\mathrm{MeHg}$ in muscle tissue, the liver and gonads of big head carp $(\mathrm{r}=0.75 ; 0.96$ and $0.67 ; \mathrm{n}=$ 7 ) and for $\mathrm{THg}$ in muscle tissue of big head carp $(\mathrm{r}=0.67 ; \mathrm{n}=7)$. No significant correlations were found in tissues of other fish. This may be due to the small number of specimens tested, and also by different life history of individual fish. Significant correlations between THg levels in fish tissues, and particularly in musculature, have been reported by a number of authors (Norstrom et al. 1976; Jewett et al. 2003; Peňáz et al. 1979). In most of the cases, however, they tested a larger number of fish.

Comparison with historical dates

The results obtained were compared with the results of THg monitoring in selected fish species from the Skalka reservoir carried out in 1995 and 1996 (Černá and Hrabětová 1996; Svobodová et al. 1997). THg levels in muscle tissue of asp caught in 1995 (1.63$3.04 \mathrm{mg} \cdot \mathrm{kg}^{-1}$ w.W., mean value $2.37 \pm 0.57 \mathrm{mg} \cdot \mathrm{kg}^{-1} \mathrm{~W} . \mathrm{W} ., \mathrm{n}=6$ ) were significantly lower $(p<0.05)$ than THg levels in asp caught in 2003 (Tab. 2). There were no significant differences in THg levels in muscle tissue between bream caught in $1996(0.32-1.38$ $\mathrm{mg} \cdot \mathrm{kg}^{-1}$ w.w., mean value $1.08 \pm 0.54 \mathrm{mg} \cdot \mathrm{kg}^{-1}$ w.w., $\left.\mathrm{n}=5\right)$ and the bream caught in 2003 (Table 2). Neither were there any significant differences in $\mathrm{THg}$ levels in muscle tissue between roach caught in $1996\left(0.38-0.70 \mathrm{mg} \cdot \mathrm{kg}^{-1} \mathrm{~W} . \mathrm{w}\right.$., mean value $0.51 \pm 0.13 \mathrm{mg} \cdot \mathrm{kg}^{-1}$ $\mathrm{w} . \mathrm{w} ., \mathrm{n}=5$ ) and the roach caught in 2003. It follows from the comparison that there were no significant changes in the total mercury content in the Skalka reservoir in the period following the 1995 - 1996 monitoring in spite of the fact that the source of contamination had been removed. At a number of other sites, mercury levels in fish muscle tissue decreased following the removal of the source of contamination (Strong 1981; Busch 1983). Transport of mercury in water ecosystems depends, of course, mainly on local conditions, both natural (Lange et al. 1993) and, in the case of artificial lakes, on technical conditions. The water level in the Skalka reservoir may drop as a result of both scheduled and unscheduled water discharges from the reservoir, which exposed approximately a half of the reservoir area (Vondrák et al. 1984). Consequently sediments shift, contaminated sediments get exposed and dry, and the deep-deposited mercury is then released back into the water ecosystem.

Assessment of health risk

In the assessment of heath risks posed by eating fish from the Skalka reservoir, the authors used the maximum $\mathrm{THg}$ and $\mathrm{MeHg}$ doses allowed by $\mathrm{FAO} / \mathrm{WHO}$, i.e. $0.3 \mathrm{mg}$ $\mathrm{THg} /$ person/week and $0.2 \mathrm{mg} \mathrm{MeHg} /$ person/week. Health risks were evaluated for asp as a representative of predatory species and for bream as a representative of non-predatory species. Using THg values, the maximum weekly recommended consumption of the fish would then be $96 \mathrm{~g}$ of asp or $305 \mathrm{~g}$ of bream. Using MeHg levels, the figures would be $59 \mathrm{~g}$ of asp or $185 \mathrm{~g}$ of bream. In view of the MeHg-to-THg ratio, it is much more appropriate to choose $\mathrm{MeHg}$ levels for food safety assessments. It follows from the above values that eating the fish poses a major health risk and a regular consumption of particularly of predatory fish from Skalka cannot be recommended under any circumstances. THg content in muscle tissues in all the fish also exceed $0.5 \mathrm{mg} \cdot \mathrm{kg}^{-1} \mathrm{~W} . \mathrm{W}$., which in many countries is the statutory limit for THg levels in fish for human consumption. The assessment of heath risks is valid on condition that fish from Skalka reservoir is the only source of mercury in food.

\section{Kontaminace ryb celkovou rtutí a methylrtutí v nádrži Skalka: případová studie}

Cílem této práce bylo zjistit a zhodnotit stav zatížení tkání ryb z údolní nádrže Skalka v České republice celkovou rtutí a methylrtutí. Tato nádrž byla několik desítek let znečištována odpadními vodami obsahujícími rtut. V srpnu 2003 bylo odloveno celkem 30 
kusů ryb, z toho: 5 kusů plotice obecné (Rutilus rutilus), 8 kusů cejna velkého (Abramis brama), 2 kusy cejnka malého (Blicca bjoerkna), 7 kusů tolstolobika pestrého (Aristichthys nobilis), 4 kusy bolena dravého (Aspius aspius), 3 kusy úhoře říčního (Anguilla anguilla) a 1 kus sumce velkého (Silurus glanis). K analýzám byla použita svalovina, játra a gonády. Průměrný obsah celkové rtuti byl ve svalovině bolena dravého (jako zástupce dravých druhů) $3,11 \pm 0,20 \mathrm{mg} \cdot \mathrm{kg}^{-1}$ a u cejna velkého (jako zástupce nedravých druhů) $0,96 \pm 0,22$ $\mathrm{mg} \cdot \mathrm{kg}^{-1}$. Všechna celková rtut byla ve svalovině bolena dravého a cejna velkého ve formě methylrtuti. Obsah celkové rtuti a methylrtuti byl signifikantně $(p<0,05)$ vyšší ve svalovině a játrech ve srovnání s gonádami. Průměrný poměr methylrtuti a celkové rtuti byl ve svalovině 1,012 , v játrech 0,545 a v gonádách 0,907 .Výsledky ukazují na stále vysokou kontaminaci nádrže Skalka rtutí, na vysoké hygienické riziko konzumace zejména dravých ryb a na převažující podíl methylrtuti v tkáních ryb.

\section{Acknowledgement}

The study was supported by the project MSM6215712402 (Ministry of Education,Youth and Sports of the Czech Republic).

\section{References}

ASSOCIATION OF OFFICIAL ANALYTICAL CHEMISTS, Official Methods of Analysis 1992: 988.11

BARUŠ B, OLIVA O et al. 1995a: Mihulovci Petromyzontes a ryby Osteichthyes (1). Academia Praha, 623 p.

BARUŠ B, OLIVA O et al. 1995b: Mihulovci Petromyzontes a ryby Osteichthyes (2). Academia Praha, 698 p.

BRABO ED, SANTOS ED, JESUS IM, MASCARENHAS AF, FAIAL KF 2000: Mercury contamination of fish and exposures of an indigenous community in Para State, Brazil. Environ Res 84: 197-203

BUSCH W-DN 1983: Decline of mercury in young fishes from Western Lake Erie between 1970-71 and 1974. Prog Fish Cult 45: 202-206

CARICCHIA AM, MINERVINI G, SOLDATI P, CHIAVARINI S, UBALDI C, MORABITTO R 1997: GC-ECD determination of methylmercury in sediment samples using a SPB-608 capillary column after alkaline digestion. Microchem J 55: 44-55

COMPEAU GC, BARTHA R 1985: Sulfate-reducing bacteria: principal methylators of mercury in anoxic estuarine sediments. Appl Environ Microb 50: 498-502

ČERNÁ E, HRABĚTOVÂ S 1996: Zpráva o výsledcích sledování cizorodých látek v roce 1996. Údolní nádrže Skalka, Rímov a Lučina. Report MZe ČR: 64-66

HEJTMÁNEK M, SVOBODOVÁ Z, STUDNICKA M 1975: Total mercury content in the musculature of fishes from some dam lakes in Bohemia. Acta Vet Brno 44: 53-58

IGATA A 1986: Clinical aspects of Minamata disease. In „Recent Advances in Minamata Disease Studies Methylmercury poisoning in Minamata and Niigata, Japan“ (Tsubaki T and Takahashi H, Eds). Kodansha, Tokyo, Japan. pp. 41-56

JERNELÖV A 1973: A new biochemical pathway for the methylation of mercury and some ecological considerations. Sci Technol 7: 712-718

JEWETT SC, ZHANG X, SATHY NAIDU A, KELLEY JJ, DASHER D, DUFFY LK 2003: Comparison of mercury and methylmercury in northern pike and Arctic grayling from western Alaska rivers. Chemosphere 50: 383-92

KANNAN K, SMITH RG, LEE RF, WINDOM HL, HEITMULLER PT, MACAULEY JM, SUMMERS JK 1998 : Distribution of total mercury and methylmercury in water, sediment, and fish South Florida estuaries. Environ Contam Toxicol 34: 109-118

LANGE TR, ROYALS HE, CONNER LL, 1993: Influence of water chemistry on mercury concentration in largemouth bass from Florida lakes. Trans Am Fish Soc 122: 74-84

MASON RP, REINFELDER JR, MOREL FMN 1995: Bioaccumulation of mercury and methylmercury. Water Air Soil Polut 80: 915-921

NORSTROM RJ, MCKINNON AE, DE FREITAS ASW 1976: A bioenergetics-based model for pollutant accumulation by fish: simulation of PCB and methylmercury residue levels in Ottawa River yellow perch (Perca avescens). Can J Fish Aqua Sci 33: 248-276

PEŇÁZ M, SVOBODOVÁ Z, HEJTMÁNEK M, TRNKOVÁ J 1979: Mercury contents in muscles of fishes from the Jihlava river. Folia Zoologica 28: 171-176

PORCELLA D 1994: Biogeochemistry. In: Watras CJ, Huckabee JW (Eds), Mercury pollution: Integration and synthesis. CRC Press, Boca Raton, FL, pp. 3-19

STRONG T 1981: Mercury decline in Lake St. Clair shencouraging. Sport Fish Inst Bull 329: 7-8

SVOBODOVÁ Z, HEJTMÁNEK M, 1976: Total mercury content in the musculature of fishes from the river Ohře and its tributaries. Acta Vet Brno 45: 45-49 
SVOBODOVÁ Z, HEJTMÁNEK M, PŘIKRYL I, KOCOVÁ A 1988: The content of total mercury in the individual components of the ecosystem of the Želivka water supply reservoir. II. Fish. Buletin VURH Vodňany 24: 3-15

SVOBODOVÁ Z, VYKUSOVÁ B, GROCH L, KOLÁŘOVÁ J, MACHALA M, MODRÁ H 1997: Výsledky chemického a biologického monitoringu na údolních nádržích Skalka, Lučina a Ř́mov. Sborník Toxicita a biodegradabilita odpadů a látek významných ve vodním prostředí. VÚRH Vodňany, Aquachemie Ostrava, pp. 299-315

VONDRÁK L, BŘEŽNÝ I, DOBÍHAL R 1984: Problematika znečištění nádrže Skalka rtutí. Research Report No. 1/81, Povodí Ohře Chomutov: 33 p.

WHO 1990: Methylmercury. In "Environmental Health Criteria”. World Health Organization, Geneva. 